\title{
Tip 2 Diyabetli Kadınların Kontrasepsiyon Kullanım Davranışları: Bir Kamu Hastanesi Örneği
}

\author{
Selda ÇELİK ${ }^{1} \bowtie$, Feride TAŞKIN YILMAZ² ${ }^{2}$, Gülden ANATACA $^{3} \oplus$, Elif BÜLBÜL ${ }^{1} \oplus$ \\ ${ }^{1}$ Sağlık Bilimleri Üniversitesi, Hamidiye Hemşirelik Fakültesi, İstanbul, Türkiye \\ ${ }^{2}$ Sivas Cumhuriyet Üniversitesi Suşehri Sağlık Yüksekokulu, Sivas, Türkiye \\ ${ }^{3}$ Sağlık Bilimleri Üniversitesi, Kanuni Sultan Süleyman Eğitim ve Araştırma Hastanesi, Diyabet Polikliniği, İstanbul , Türkiye
}

Bu makaleye yapılacak atıf: Çelik S ve ark. Tip 2 Diyabetli Kadınların Kontrasepsiyon Kullanım Davranıșları: Bir Kamu Hastanesi Örneği. Turk J Diab Obes 2021;2: 165-172.

\begin{abstract}
ÖZ
Amaç: Üreme çağındaki diyabetli kadınlarda, anne ve bebek sağlığı açısından planlı gebelik önemlidir. Bu dönemde istenmeyen gebeliklerin önlenmesi açısından doğru kontrasepsiyon yönteminin kullanılması gerekmektedir. Araştırma, tip 2 diyabetli kadınların kontrasepsiyon kullanım davranışlarını ve ilişkili faktörleri belirlemek amacıyla tanımlayıcı olarak yapılmıştır.

Gereç ve Yöntemler: Çalışmaya, bir kamu hastanesinde Diyabet polikliniğine başvuran ve üreme döneminde olan 194 tip 2 diyabetli kadın dahil edilmiştir. Veriler kadınların sosyodemografik ve hastalık özellikleri ile kontrasepsiyon yöntemi kullanmaya ilişkin bilgilerini sorgulayan tanılama formu ile elde edilmiş̧ir. Verilerinin değerlendirilmesinde bağımsız gruplarda t testi ve Ki-kare testi kullanılmıştır. Bulgular: Çalışmaya katılan diyabetli kadınların \%54,6’sı kontrasepsiyon yöntemi kullandığını ve en fazla geri çekme (\%40,5) ile kondom $(\% 39,7)$ yönetimini tercih ettiğini belirtmiştir. Kadınların sadece \%33,5'inin kontrasepsiyon konusunda sağlık profesyonellerinden bilgi aldığı tespit edilmiştir. Kontrasepsiyon kullanan kadınların \%19,9'unun kontrasepsiyon seçimi için hekime danıştığı ve \%38,6'sının ucuz/ bedava olması nedeniyle kullandığı yöntemi tercih ettiği belirlenmiştir. Çalışmada üç ve üzeri çocuk sayısı bulunan ve kontrasepsiyon ile ilgili bilgi alan kadınların kontrasepsiyon kullanma oranlarının daha yüksek olduğu, bununla birlikte ileriye yönelik gebelik düşüncesi olmayan kadınların daha düşük oranda kontrasepsiyon kullandığı tespit edilmiştir.
\end{abstract}

Sonuç: Çalışmada diyabetli kadınların sadece yarısının kontrasepsiyon yöntemi kullandıkları, kontrasepsiyon kullanmada çocuk sayısının, kontrasepsiyon ile ilgili bilgi alma durumunun ve ileriye yönelik gebelik düşüncesinin ilişkili olduğu belirlenmiştir.

Anahtar Sözcükler: Tip 2 diyabet, Kontrasepsiyon, Aile planlaması, Davranış

\section{Contraception Usage Behavior of Women with Type 2 Diabetes: An Example of a Public Hospital}

\begin{abstract}
Aim: Planned pregnancy is important in terms of maternal and infant health in women with diabetes of reproductive age. In this period, it is necessary to use the correct contraception method to prevent unwanted pregnancies. The study was conducted to determine contraception use behaviors and related factors of women with type 2 diabetes.

Material and Methods: The study included 194 women with type 2 diabetes who applied to a diabetes outpatient clinic in a public hospital and were in their reproductive period. The data were obtained with a diagnosis form that inquired about the sociodemographic and disease characteristics of women and their knowledge about using contraception. In the evaluation of the data, t test and Chi-square test were used in independent groups.

Results: In the study, it was determined that $54.6 \%$ of the diabetic women used contraception method and preferred the most coitus interruptus (40.5\%) and condom (39.7\%) management. It was found that only $33.5 \%$ of women received information about contraception from health professionals. It was determined that $19.9 \%$ of the women using contraception consulted the physician for the choice of
\end{abstract}

ORCID: Selda Çelik / 0000-0003-4328-3189, Feride Taşkın Yılmaz / 0000-0003-0568-5902, Gülden Anataca / 0000-0002-2999-4462, Elif Bülbül / 0000-0001-8920-1041 
contraception and $38.6 \%$ preferred the method they used because it was cheap / free. In the study, it was found that women with three or more children and who received information about contraception had a higher rate of using contraception, however, women who had no prospective pregnancy thought used contraception at a lower rate.

Conclusion: In the study, it was determined that only half of the women with diabetes used contraception method. It was determined that the use of contraception and the number of children, the state of obtaining information about contraception and the prospective pregnancy idea were associated.

Keywords: Type 2 diabetes, Contraception, Family planning, Behavior

\section{GİRIŞ}

Diyabet, dünya çapında bireylerin, ailelerin ve toplumların yaşamları ve refahı üzerinde büyük etkisi olan ciddi ve uzun vadeli sağlik problemidir. Yetişkinlerde ilk 10 ölüm nedeni arasında yer alan diyabet sıklığının 2030 yılında \%10,2'ye (578 milyon) ve 2045 yılında \%10,9'a (700 milyon) yükseleceği tahmin edilmektedir (1). Diyabetin artan bu siklığı göz önüne alındığında, üreme çağında olan çok sayıda diyabetli kadın plansız ve yetersiz koșullarda gebe kalabilmektedir (2). Bu açıdan diyabetli kadınlar üreme sağlı̆̆ 1 ve gebeliği önleme konusunda ele alınması gereken önemli gruplardan biridir (3).

Diyabet, kadının doğurganlığını etkilememekle birlikte, gebeliği etkileyen en yaygın tıbbi durumlardan biridir $(2,4)$. Gebelik döneminde meydana gelen hormonal değişiklikler, karbonhidrat ve yağ metabolizmasında değişime yol açarak, diyabetin kontrolünü güçleştirebilmekte, anne ile fetüsün sağlığını olumsuz yönde etkileyebilmektedir $(5,6)$. Bununla birlikte, kötü glisemik kontrole sahipken meydana gelen planlanmamış gebelik, ölü doğum, konjenital anormallikler, perinatal mortalite, erken doğum, preeklampsi, makrozomi, bebeğin daha sonraki yaşamında obezite ve diyabet riskini artıran fetal programlama gibi komplikasyonlara neden olabilmektedir (4,5,7-10). Bu nedenle, diyabetli kadınlarda planlı gebelik zorunlu olup (11), glisemik kontrol sağlanana kadar etkili kontrasepsiyon kullanımına daha fazla önem verilmesi gerekmektedir $(7,10,12,13)$.

Kontrasepsiyon, diyabetli kadının gebelik öncesi bakımının önemli bir bileşeni olmakla birlikte (14), ne yazık ki sağlık profesyonelleri tarafından göz ardı edilebilen bir konudur $(8,13,15)$. Diyabetli kadınlara hizmet veren sağlık profesyonellerinin, kontrasepsiyon tercihi konusunda kadınlara bilinçli seçimler yapabilmesi konusunda yardımcı olabilmesi gerekmektedir (7). Genel olarak, diyabetli kadınların kontrasepsiyon gereksinimleri, diyabeti olmayan kadınlardan farklı değildir $(8,11,16)$. Fakat bu kadınlara kontrasepsiyon danışmanlığ 1 yapılırken; yöntemin uzun ya da kısa süreli kullanılacak olması, diyabetin tipi, hastalığın süresi, diyabetik komplikasyonların varlığı, kadının beden kitle indeksi, kardiyovasküler hastalık riski ve gelecekte gebelik planlayıp planlamadığı gibi çok sayıda özel durumun dikkate alınması gereklidir (17). Çünkü diyabette uygun olmayan kontrasepsiyon kullanımı, metabolik bozuklukların ve vasküler komplikasyonların artmasına yol açabilir $(6,18)$. Dünya Sağlık Örgütü, diyabetli kadınlara yönelik kontrasepsiyon yöntemlerin belirlenmesi için kılavuz düzenlemiş ve bu k1lavuz doğrultusunda diyabetli kadınlara kontrasepsiyon seçilmesi gerektiği belirtilmiştir (19).

Yüksek gebelik riski olan üreme çağındaki diyabetli kadınlarda kontrasepsiyon kullanımı, istenmeyen bir gebeliğe karşı, her zaman daha güvenli yöntemdir (20). Buna rağmen yapılan çalışmalarda, diyabetli kadınlarda sağlıklı kadınlara göre kontrasepsiyon kullanımının düşük olduğu $(12,14)$, diyabetli kadınların kontrasepsiyon yöntemi konusunda tavsiye istemekte çekingen oldukları ya da riskleri anlamadıkları (4) ve yüksek oranda planlanmamış gebelik gerçekleştirdiği (21) belirtilmektedir. Literatür incelendiğinde, Türkiye'de diyabetli kadınlarda kontrasepsiyon kullanımı ile ilgili çalışmaya rastlanmamıştır. Bu çalışma, üreme döneminde olan tip 2 diyabetli kadınların kontrasepsiyon kullanma davranışlarını ve ilişkili faktörleri belirlemek amacıyla gerçekleştirilmiştir.

\section{GEREÇ ve YÖNTEMLER}

\section{Araştırmanın Tipi ve Örneklemi}

Tanımlayıcı tipte yapılan araştırmanın evrenini Aralık 2020-Şubat 2021 tarihleri arasında Sağlık Bilimleri Üniversitesi Kanuni Sultan Süleyman Eğitim ve Araştırma Hastanesi Diyabet Polikliniği’ne başvuran tip 2 diyabet tanısı almış ve üreme döneminde bulunan 645 kadın hasta oluşturmuştur. Örneklem seçimine gidilmeden belirlenen zamanda evrenin tamamına ulaşılması hedeflenmiştir. $\mathrm{Bu}$ bağlamda en az 6 aydır tip 2 diyabet tanısı alan, 18-49 yaş arası, cinsel yaşamı aktif, evli, gebe olmayan, menopoz döneminde bulunmayan, daha önce infertilite tanısı almayan, sözel iletişim engeli bulunmayan ve çalışmaya katılmayı kabul eden kadınlar çalışmaya dahil edilmiştir. Çalışmanın örneklemine 49 yaş üstü olan 368 hasta, gebe olan veya menopoz döneminde olan 62 hasta, çalışmaya katılmaya gönüllü olmayan 21 hasta dahil edilmemiş ve sonuçta araştırmanın örneklemini 194 hasta oluşturmuştur. 


\section{Veri Toplama Araçları}

Veriler tanılama formu kullanılarak elde edilmiştir. $\mathrm{Bu}$ form, araştırmacılar tarafından literatür incelemesi doğrultusunda hazırlanmış olup üç bölümden oluşmaktadır $(3,7,10,12)$. Formun ilk bölümünde kadınların sosyodemografik özellikleri (yaş, eğitim, çalışma durumu vb), sigara ve alkol kullanma alışkanlığı ile eşinin yaşını, eğitim durumu ve sağlık durumunu sorgulayan 10 soru yer almaktadır. Formun ikinci bölümünde, kadınların hastalık bilgisini içeren (hastalık süresi, tedavi şekli, komplikasyon varlığı, sağlık kontrollerini yaptırma durumu, HbAlc değeri vb) 10 ifade bulunmaktadır. Formun üçüncü bölümü ise, kadınların cinsel yaşam ve kontrasepsiyon kullanma davranış1na ilişkin bilgilerini sorgulayan altı sorudan oluşmaktadır. Kronik komplikasyonlar ve HbA1c ilişkin veriler hasta dosyalarından elde edilmiştir.

Verileri toplamadan önce, veri formu diyabet ve kadın sağlığı konusunda alanında uzman üç öğretim üyesi tarafından anlaşılırlık açısından değerlendirilmiştir. Veri formunun uzman görüşleri doğrultusunda düzenlenmesinin ardından 20 diyabetli kadın ile pilot çalışması yapılmıştır. Bu çalışma sonucunda veri toplama aracına kadınlar tarafından açık ve net bir șekilde anlaşılırlığı değerlendirilerek, alınan geri bildirimler doğrultusunda son şekli verilmiştir.

Veriler araştırmacılar tarafından rahat görüşebilecek bir odada yüz yüze görüşülerek toplanmıştır. Araştırmacılar tarafından veri formlarının doldurulması yaklaşı 20-25 dakika sürmüştür.

\section{Araştırmanın Etik Yönü}

Verileri toplamadan önce Sağllk Bilimleri Üniversitesi Kanuni Sultan Süleyman Eğitim ve Araştırma Hastanesi Klinik Araştırmalar Etik Kurulundan (Karar No: KAEK/2020.12.223) ve çalışmanın yapılacağı kurumdan yazılı izin alınmıştır. Ayrıca, çalışmada yer alan her kadın çalışmanın içeriği ve katılımın gönüllü olması hususunda bilgilendirilmiş; sözlü ve yazılı onamları alınmıştır.

\section{Araștırmanın Sınırlılıkları}

Bu çalışmanın bazı sınırlılıkları vardır. Çalışmada olasılıklı örneklem seçilmemiş olması ve katılımcıların sadece tek merkezde tip 2 diyabetli kadınlardan oluşması dolayısıyla sonuçların genellenememesi en önemli sınırlıllğı oluşturmaktadır. Ayrıca belli bir zaman aralığında yapıldığından dolayı kesitsel veriler sunulmaktadır. Ek olarak, kontrasepsiyon yöntemi kullanım davranışları kadınların öz bildirimine dayalıdır. Bu sınırlılıklara rağmen, çalışmamız ulusal düzeyde tip 2 diyabetli kadınların kontrasepsiyon kullanma davranışları ile sosyodemografik ve hastalık ile ilgili özellikleri arasındaki ilişkisini inceleyen ilk çalışmadır.

\section{İstatistiksel Analiz}

Çalışmadan elde edilen verilerin değerlendirilmesinde SSPS 22.0 programı kullanılmıștır. Katılımcıların sosyodemografik, hastalık ve kontrasepsiyon kullanımına ilişkin özelliklerinin dağılımı yüzdelik ve ortalama testi ile değerlendirilmiştir. Kadınların kontrasepsiyon kullanma davranışları ile bazı özelliklerinin karşılaştırılmasında t testi ve ki kare testi kullanılmıştır. Ayrıca kadınların kontrasepsiyon kullanma davranışlarını etkileyen çocuk sayısı, kontrasepsiyon kullanımı ile ilgili bilgi alma durumu ve ileriye yönelik gebelik düşüncesi gibi faktörleri belirlemek için Binary lojistik regresyon analizi kullanılmıştır. Verilerin değerlendirilmesinde istatistiksel anlamlılık 0,05 önem düzeyinde incelenmiştir.

\section{BULGULAR}

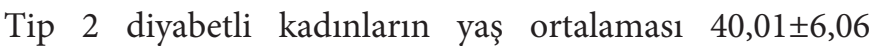
$(\min =29, \max =49)$ yll olup, \%68'i ortaöğretim mezunudur. Kadınların \%18,6'sı çocuk sahibi değilken, \%56,7'sinin bir ya da iki, \%24,7'sinin ise üç ve üzeri çocuğu bulunmaktadır. Katılımcıların \%59,3'ü bir işte çalışmakta olup, \%81,4'ü ekonomik durumunu orta düzey olarak belirtmiştir. Kadınların $\% 7,7$ 'i halen sigara içmekte ve \%3,6'sı alkol kullanmaktadır. Kadınların evlilik süresi ortalaması ise, 10,38 $\pm 7,32$ ( $\mathrm{min}=1$, $\max =32$ ) ylldir.

Tablo 1'de tip 2 diyabetli kadınların hastalık ile ilgili özellikleri verilmiştir. Hastalık süresi ortalaması $3,37 \pm 2,40$ yıl olan kadınların HbA1c değeri ortalaması $\% 8,50 \pm 1,12$ olarak bulunmuş ve tamamının glisemik hedef değerinin üzerinde $\mathrm{HbAlc}$ düzeyine sahip olduğu tespit edilmiştir. Ayrıca kadınların \%63,4'ünün diyabet dışında başka kronik hastalığı (hipertansiyon, astım, koroner arter hastalığı, migren) bulunmakta olup, \%43,3'ünün diyabete bağl1 komplikasyonu da bulunduğu belirlenmiştir.

Çalışmada kadınların \%56,7'si diyabet nedeniyle cinsel yaşamında sorun yaşadığını ve \%92,3’ü son bir yıl içerisinde jinekolojik sağlık sorunu meydana geldiğini belirtmiştir. Kadınların sadece \%33,5’i kontrasepsiyon konusunda sağlık profesyonellerinden bilgi aldığını ifade etmiştir. Çalışmada kadınların yaklaşık yarısı $(\% 54,6)$ kontrasepsiyon yöntemi kullandığını ve en fazla geri çekme $(\% 40,5)$ ile kondom $(\% 39,7)$ yönetimini tercih ettiğini belirtmiştir. Ayrıca kadınların sadece \%19,9'u kontrasepsiyon seçimi için hekime danıştığını ve \%38,6'sı ucuz/bedava olması nedeniyle kullandığ yöntemi tercih ettiğini ifade etmiştir (Tablo 2).

Çalışmada kontrasepsiyon kullanan ve kullanmayan kadınların yaş, evlilik süresi, eğitim durumu, beden yapısı, hastalık süresi, glisemik kontrol düzeyi, diyabet dışında başka kronik hastalık varlığı, diyabet nedeniyle cinsel yaşamda 
Tablo 1: Tip 2 diyabetli kadınların hastalık ile ilgili özellikleri

\begin{tabular}{lc}
\hline Özellikler & $\mathbf{n}(\%)$ \\
\hline Hastalık süresi (yıl) (Ort $\pm S S)$ & $3,37 \pm 2,40(\min =1, \max =14)$ \\
\hline HbA1c (\%) (Ort $\pm S S)$ & $8,50 \pm 1,12(\min =6,50, \max =11,20)$ \\
\hline Tedavi şekli & $1(0,5)$ \\
\hline Sadece diyet tedavisi & $155(79,9)$ \\
\hline Oral antidiyabetik tedavi & $38(19,6)$ \\
\hline Oral antidiyabetik ve insülin tedavisi & \\
\hline Diyabet dısında başka kronik hastalık varlı̆̆ı & $123(63,4)$ \\
\hline Var & $71(36,6)$ \\
\hline Yok & \\
\hline Diyabet ile ilgili kontrollerini düzenli yaptırma durumu & $87(44,8)$ \\
\hline Evet & $107(55,2)$ \\
\hline Hayır & \\
\hline Hastalığı hakkında doktor ya da hemşireden eğitim alma durumu & $75(38,7)$ \\
\hline Evet & $119(61,3)$ \\
\hline Hayır & \\
\hline Diyabete bağlı kronik komplikasyon varlığı & $84(43,3)$ \\
\hline Var* & $73(37,6)$ \\
\hline Nöropati & $70(36,1)$ \\
\hline Hipertansiyon & $17(8,8)$ \\
\hline Retinopati & $6(3,1)$ \\
\hline Nefropati & $6(3,1)$ \\
\hline İskemik Kalp Hastalığı & $110(56,7)$ \\
\hline Yok & \\
\hline BKİ değerine göre beden yapısı & $53(27,3)$ \\
\hline Normal kilolu & $133(68,6)$ \\
\hline Fazla kilolu & $8(4,1)$ \\
\hline Obez & \\
\hline
\end{tabular}

BKİ: Beden Kütle İndeksi, * Birden fazla seçenek işaretlenmiştir.

sorun yaşama durumu ve son bir yıl içerisinde jinekolojik sağlık sorunu yaşama durumu gibi özellikleri arasında istatistiksel olarak anlamlı farklılık bulunmazken ( $>00,05)$; üç ve üzeri çocuk sayısı bulunan ve kontrasepsiyon ile ilgili bilgi alan kadınların kontrasepsiyon kullanma oranlarının daha yüksek olduğu, bununla birlikte ileriye yönelik gebelik düşüncesi olmayan kadınların daha düşük oranda kontrasepsiyon kullandığı belirlenmiştir $(\mathrm{p}<0,01)$ (Tablo 3).

Tablo 4'de Tip 2 diyabetli kadınların kontrasepsiyon kullanma davranışlarını etkileyen faktörler verilmiştir. Regresyon analizi sonuçlarına göre çocuk sayısı ve ileriye yönelik gebelik düşüncesinin olmamasının kontrasepsiyon kullanma davranışlarını etkilediği belirlenmiştir $(\mathrm{p}<0,001)$. Kontrasepsiyon ile ilgili bilgi alma durumu ile kontrasepsiyon kullanma davranışları arasında ilişki olmadığı bulunmuştur $(\mathrm{p}>0,05)$.

\section{TARTIŞMA}

Diyabetli kadınlarda glikoz kontrolü sağlanana kadar etkili kontrasepsiyon kullanımı, bu yüksek riskli popülasyonda sağlıklı bir gebelik süreci geçirmek ve sağlıklı bebeklere sahip olmak için anahtar faktörlerinden biridir (12). Bu çalışmada, tip 2 diyabetli kadınların kontrasepsiyon kullanım davranışları ve ilişkili faktörler incelenmiş olup, elde edilen bulgular literatür doğrultusunda tartışılmıştır.

Diyabetli kadınların planlanmamış gebeliklerden kaçınma noktasında kontrasepsiyon yöntemlerini kullanması yaşamsal öneme sahiptir (11,22). Çalışmada, kadınların sadece yarısının kontrasepsiyon yöntemi kullandığı tespit edilmiştir. Yapılan başka çalışmalarda, diyabetli kadınların kontrasepsiyon kullanma oranlarının \%34-71,2 arasında değiştiği, sağlıklı kadınlara oranla kontrasepsiyon kullanma oranlarının daha düşük olduğu saptanmıştır $(7,10,23)$. 
Tablo 2: Tip 2 diyabetli kadınların cinsel yaşam, jinekolojik sağlık durumu ve kontrasepsiyon kullanma durumlarına ilișkin özellikleri

\begin{tabular}{|c|c|}
\hline Özellikler & n (\%) \\
\hline \multicolumn{2}{|c|}{ Diyabet nedeniyle cinsel yaşamda sorun yaşama durumu } \\
\hline Evet & $110(56,7)$ \\
\hline Hayır & $84(43,3)$ \\
\hline \multicolumn{2}{|c|}{ Son bir yıl içerisinde jinekolojik sağlık sorunu yaşama durumu } \\
\hline $\operatorname{Var}^{*}$ & $179(92,3)$ \\
\hline İdrar yolu enfeksiyonu & $159(82,0)$ \\
\hline Genital bölgede kaşıntı & $173(89,2)$ \\
\hline Vajinal akıntı & $93(47,9)$ \\
\hline İdrar inkontinansı & $66(34,0)$ \\
\hline Menstrual düzensizlik & $8(4,1)$ \\
\hline Yok & $15(7,7)$ \\
\hline \multicolumn{2}{|c|}{ Diyabet tanısı aldıktan sonra hekim ya da hemşireden kontrasepsiyon ile ilgili bilgi alma durumu } \\
\hline Evet & $65(33,5)$ \\
\hline Hayır & $129(66,5)$ \\
\hline \multicolumn{2}{|c|}{ Kontrasepsiyon yöntemi kullanma durumu } \\
\hline Evet $^{* *}$ & $106(54,6)$ \\
\hline Geri çekme & $43(40,5)$ \\
\hline Kondom & $42(39,7)$ \\
\hline Oral kontraseptif & $15(14,1)$ \\
\hline Rahim içi araç & $6(5,7)$ \\
\hline Hayır & $88(45,4)$ \\
\hline \multicolumn{2}{|c|}{ Kontrasepsiyon seçimi için hekime danışma durumu $(n=106)^{*}$} \\
\hline Evet & $21(19,9)$ \\
\hline Hayır & $85(80,1)$ \\
\hline \multicolumn{2}{|c|}{ Kullanılan kontrasepsiyon yönteminin tercih nedeni $(n=106)^{\star}$} \\
\hline Ucuz/bedava olması & $41(38,6)$ \\
\hline Kolay temin edilmesi & $29(27,3)$ \\
\hline Kullanımın kolay olması & $24(22,7)$ \\
\hline Diğerlerine göre daha etkili olması & $7(6,7)$ \\
\hline Hekim önerisi & $5(4,7)$ \\
\hline \multicolumn{2}{|l|}{ İleriye yönelik gebelik düşüncesi } \\
\hline Var & $37(19,1)$ \\
\hline Yok & $140(72,2)$ \\
\hline Kararsiz & $17(8,8)$ \\
\hline
\end{tabular}

*Birden fazla seçenek işaretlenmiştir. ${ }^{* \star} \mathrm{n}$ sayısı değişkenlik göstermektedir.

Çalışma bulgusu, literatür ile uyumlu olmakla birlikte, diyabetli kadının sağlı̆̆ açısından olumlu değildir. Diyabetli kadınların hastalık yönetimine ek olarak kontrasepsiyon danışmanlığına da ihtiyacı olduğu görülmektedir.

Diyabetli kadınlar, genel popülasyonla aynı kontraseptif seçimine sahiptir, ancak seçilen hormonal yöntemlerin potansiyel metabolik etkilerine dikkat edilmesi gerekmektedir (8). Bu nedenle diyabetli kadinlarda hormonal olmayan kontraseptifler daha güvenlidir (20). Çalışmada, kadınların kullandıkları yöntemler incelendiğinde, \%40,5'inin geri çekme, \%39,7'sinin kondom, \%14,1'inin oral kontraseptif ve \%5,7'sinin rahim içi araç yönetimini tercih ettiği belirlenmiştir. Evangelista ve ark. çalışmasında, diyabetli kadınların kontrasepsiyon yöntemi olarak \%44'ünün kondom, $\% 34,6$ sinin kombine oral kontraseptif, \%12,5'inin kombine enjektabl kontraseptif, \%6,7'sinin takvim yöntemi, 
Tablo 3: Tip 2 diyabetli kadınların kontrasepsiyon kullanma davranışları ile bazı özelliklerinin karşılaştırılması

\begin{tabular}{|c|c|c|c|}
\hline Özellikler & $\begin{array}{c}\text { Kontrasepsiyon Kullanan } \\
n=106(\%)\end{array}$ & $\begin{array}{c}\text { Kontrasepsiyon Kullanmayan } \\
n=88(\%)\end{array}$ & Test; p \\
\hline Yaş (yıl) & $40,45 \pm 5,92$ & $39,48 \pm 6,21$ & $\mathrm{t}=1,105 ; 0,271$ \\
\hline Evlilik süresi (yıl) & $11,03 \pm 7,90$ & $9,59 \pm 6,51$ & $t=1,373 ; 0,171$ \\
\hline \multicolumn{3}{|l|}{ Eğitim durumu } & \multirow{4}{*}{$\begin{array}{c}\chi^{2}=5,816 \\
0,055\end{array}$} \\
\hline İlköğretim & $21(19,8)$ & $16(18,2)$ & \\
\hline Ortaöğretim & $66(62,3)$ & $66(75,0)$ & \\
\hline Yükseköğretim & $19(17,9)$ & $6(6,8)$ & \\
\hline \multicolumn{3}{|l|}{ Çocuk sayısı } & \multirow{4}{*}{$\begin{aligned} \chi^{2} & =84,262^{\star} \\
& <\mathbf{0 . 0 0 1}\end{aligned}$} \\
\hline Yok & $34(32,1)$ & $2(2,3)$ & \\
\hline $1-2$ & $30(28,3)$ & $80(90,9)$ & \\
\hline 3 ve üzeri & $42(39,6)$ & $6(6,8)$ & \\
\hline \multicolumn{3}{|c|}{ BKİ değerine göre beden yapısı } & \multirow{4}{*}{$\begin{array}{c}\chi^{2}=2,582^{*} \\
0,259\end{array}$} \\
\hline Normal kilolu & $32(30,2)$ & $21(23,9)$ & \\
\hline Fazla kilolu & $68(64,2)$ & $65(73,9)$ & \\
\hline Obez & $6(5,7)$ & $2(2,3)$ & \\
\hline Hastalık süresi (yıl) & $3,48 \pm 2,75$ & $3,25 \pm 1,90$ & $t=0,665 ; 0,507$ \\
\hline HbA1c değeri (\%) & $8,54 \pm 1,09$ & $8,46 \pm 1,16$ & $\mathrm{t}=0,521 ; 0,603$ \\
\hline \multicolumn{3}{|c|}{ Diyabet dışında başka kronik hastalık varlığı } & \multirow{3}{*}{$\begin{array}{c}\chi^{2}=0,921 \\
0,259\end{array}$} \\
\hline Var & $42(39,6)$ & $29(33,0)$ & \\
\hline Yok & $64(60,4)$ & $59(67,0)$ & \\
\hline \multicolumn{3}{|c|}{ Diyabete bağlı kronik komplikasyon varlığı } & \multirow{3}{*}{$\begin{array}{c}\chi^{2}=0,375 \\
0,563\end{array}$} \\
\hline Var & $48(45,3)$ & $36(40,9)$ & \\
\hline Yok & $58(54,7)$ & $52(59,1)$ & \\
\hline \multicolumn{3}{|c|}{ Diyabet nedeniyle cinsel yaşamda sorun yaşama durumu } & \multirow{3}{*}{$\begin{array}{c}\chi^{2}=0,711 \\
0,399\end{array}$} \\
\hline Evet & $63(59,4)$ & $47(53,4)$ & \\
\hline Hayır & $43(40,6)$ & $41(46,6)$ & \\
\hline \multicolumn{3}{|c|}{ Son bir yıl içerisinde jinekolojik sağlık sorunu yaşama durumu } & \multirow{3}{*}{$\begin{array}{c}\chi^{2}=0,417 \\
0,518\end{array}$} \\
\hline Var & $99(93,4)$ & $80(90,9)$ & \\
\hline Yok & $7(6,6)$ & $8(9,1)$ & \\
\hline \multicolumn{3}{|c|}{ Kontrasepsiyon ile ilgili bilgi alma durumu } & \multirow{3}{*}{$\begin{aligned} \chi^{2} & =80,734^{\star} \\
& <\mathbf{0 . 0 0 1}^{\star *}\end{aligned}$} \\
\hline Evet & $65(61,3)$ & $0(0,0)$ & \\
\hline Hayır & $41(38,7)$ & $88(100,0)$ & \\
\hline \multicolumn{3}{|c|}{ İleriye yönelik gebelik düşüncesi } & \multirow{4}{*}{$\begin{aligned} \chi^{2} & =28,776^{\star} \\
& <\mathbf{0 . 0 0 1}^{\star *}\end{aligned}$} \\
\hline Var & $34(32,1)$ & $3(3,4)$ & \\
\hline Yok & $64(60,4)$ & $76(86,4)$ & \\
\hline Kararsiz & $8(7,5)$ & $9(10,2)$ & \\
\hline
\end{tabular}

BKİ: Beden Kütle İndeksi. ${ }^{*}$ Gözlerde 5 ’ten küçük beklenen sayı olduğu için Fisher Fisher Exact testi kullanılmıştır. ${ }^{* *}$ p $<0.01$

Tablo 4: Tip 2 diyabetli kadınların kontrasepsiyon kullanma davranışlarını etkileyen faktörler

\begin{tabular}{lccccc}
\hline & B & Exp (B) & p & \multicolumn{2}{c}{ \%95 GA } \\
\hline & & & & Alt değer & Alt değer \\
\hline Çocuk sayısı & $-1,666$ & 0,189 & $0,000^{*}$ & 0,077 & 0,463 \\
\hline Kontrasepsiyon ile ilgili bilgi alma durumu & 21,953 & 3,422 & 0,996 & 0,000 &. \\
\hline İleriye yönelik gebelik düşüncesi & 1,690 & 5,419 & $0,006^{*}$ & 1,606 & 18,284 \\
\hline Sabit & $-42,919$ & $<0.001$ & 0,996 & & \\
\hline
\end{tabular}

${ }^{*} \mathrm{p}<0.001$. GA: Güven aralı̆̆ı. 
\%4,8'inin rahim içi araç, \%4,8'inin geri çekme ve \%2,9'unun acil kontrasepsiyon kullandığı belirlenmiştir (24). Başka bir çalışmada ise, diyabetli kadınların \%37,6'sının daha etkili kontrasepsiyon (tüpligasyon, vazektomi, rahim içi araç, oral kontraseptifler), \% 33,6'sının ise daha az etkili kontrasepsiyon (kondom, diyafram, takvim yöntemi, acil kontrasepsiyon ilacı, coitus interruptus, spermisit köpüğü) kullandığ belirlenmiştir. Aynı çalışmada diyabetli kadınların, normoglisemik kadınlara göre etki düzeyi düşük kontrasepsiyon yöntemi kullanma oranlarının daha yüksek olduğu tespit edilmiştir (10). Diyabetli kadınlarla yapılan bir diğer çalışmada da, \%79,1'inin gebelik düşünmemesine rağmen, $\% 29,9$ 'unun sterilizasyon, rahim içi cihaz, implanon ve oral kontraseptif; \%29.9' 'unun kondom ve \%40,3'ünün takvim yöntemi, laktasyon amenore yöntemi veya geri çekme yöntemini kullandıkları belirlenmiştir. Aynı çalışmada "Kullandığınız mevcut doğum kontrol yönteminin gebeliği önlemede etkili olduğunu düşünüyor musunuz?" sorusuna katılımciların sadece $\% 58,2$ 'sinin yanıt verdiği tespit edilmiştir (3). Çalışma bulgusu literatür ile uyumlu olmakla birlikte, diyabetli kadınlarda gebeliği önlemede etkili kontrasepsiyon yöntemlerinin kullanılmadığını ortaya koymaktadır.

Diyabetli kadınlarda kontrasepsiyon kullanımı, sağlık profesyonelleri tarafindan nadiren ele alınan konulardan biri (8) olmakla birlikte kontrasepsiyon yöntemleri konusunda danışmanlık yapılması son derece önemlidir (20). Çalışmada diyabetli kadınların sadece \%33,5'inin kontrasepsiyon konusunda sağlik profesyonellerinden bilgi ald1$\breve{g} 1$, kontrasepsiyon kullanan diyabetli kadınların ise sadece \%19,9'unun kontrasepsiyon seçimi için hekime danıştığ belirlenmiştir. Yapılan bir çalışmada, diyabetli kadınların \%16'sının kontrasepsiyonla ilgili herhangi bir tavsiye almadığı; kontrasepsiyonla ilgili danışmanlık alanların ise $\% 49$ 'unun pratisyen hekimlerden, \%9'unun bir aile planlaması kliniğinden, \%7'sinin diyabet kliniğinde bulunan doktordan, \%9'unun hemşireden ve \%4'ünün jinekolog tarafından tavsiye aldığı belirlenmiştir (13). Başka bir çalışmada da, diyabetli kadınların sadece \%4'ünün kontrasepsiyon danışmanlığ 1 aldığı, diyabeti olmayan kadınlara göre kontrasepsiyon danışmanlığı alma durumlarının önemli ölçüde daha düşük olduğu tespit edilmiştir (15). Diğer bir çalışmada da, diyabetli kadınların yaklaşık yarısının (\%53), sağlık bakım desteği almadan kendi başına bir yöntem kullandığ belirlenmiştir (24). Diyabetli kadınlarda kontrasepsiyon kullanımının incelendiği ve "Kimsenin benimle gerçekten bunun hakkında konuşmaması komik" başlıklı niteliksel bir çalışmada da, diyabet uzmanları ile diyabetli kadınlar arasinda kontrasepsiyon tavsiyesi ve kullanımında uyumsuzluk olduğu tespit edilmiştir (7). Çalışma bulgusu, diyabetli kadınlarda kontrasepsiyon kullanımının yeterli düzeyde ele alınmadığını ortaya koymaktadır.
Çalışmada kontrasepsiyon kullanan diyabetli kadınların \%38,6'sının ucuz/bedava olması, \%27,3'ünün kolay temin edilmesi, \%22,7'sinin kullanımının kolay olması, \%6,7'sinin diğerlerine göre daha etkili olması ve $\% 4,7$ 'sinin hekim önerisi nedeniyle kullandığ 1 yöntemi tercih ettiği belirlenmiştir. Diyabetli kadınlarla yapılan bir çalışmada, kadınların \%37'sinin etkili ve güvenilir olması, \%20'sinin tıbbi durumun başka yöntemlere izin vermemesi, \%10'unun menstruasyonu düzenlemesi ve $\% 6$ 'sinın hekimin önermesi nedeniyle kullandıkları yöntemleri tercih ettikleri tespit edilmiștir (7).

Çalışmada kontrasepsiyon kullanan ve kullanmayan kadınların yaş, evlilik süresi, eğitim durumu, beden yapısı, hastalık süresi, glisemik kontrol düzeyi, diyabet dışında başka kronik hastalık varlığı, diyabet nedeniyle cinsel yaşamda sorun yaşama durumu ve son bir yıl içerisinde jinekolojik sağlık sorunu yaşama durumu gibi özellikleri arasında farklılık olmadığı, buna rağmen üç ve üzeri çocuk sayısı bulunan ve kontrasepsiyon ile ilgili bilgi alan kadınların kontrasepsiyon kullanma oranlarının daha yüksek olduğu, bununla birlikte ileriye yönelik gebelik düşüncesi olmayan kadınların daha düşük oranda kontrasepsiyon kullandığı belirlenmiştir. Literatürde diyabetli kadınların sosyodemografik, hastalık ve jinekolojik özellikleri ile kontrasepsiyon kullanma davranışları arasındaki ilişkiyi ortaya koyan çalışmalar oldukça sınırlıdır. Yeni teşhis edilen 24-32 yaş diyabetli kadınlarla yapılan bir çalışmada, katılımcıların kontrasepsiyon kullanma durumları ile eğitim ve beden yapısı arasında ilişki olmadığı saptanmıştır. Buna rağmen aynı çalışmada, HbAlc değeri \%6,5'in altında olan kadınların yüksek etkili kontraseptif kullanım oranının, HbAlc değeri \%6,5 ve üzerinde olanlara göre daha yüksek olduğu tespit edilmiştir (10). Çalışma bulgusu, kadınlarda kontrasepsiyon kullanma davranışlarını etkileyen faktörleri belirlemek amacıyla daha fazla bilimsel çalışmaya ihtiyaç olduğunu ortaya koymaktadır.

Çalışmanın sonucunda diyabetli kadınların sadece yarısının kontrasepsiyon yöntemi kullandıkları, kontrasepsiyon kullanmada çocuk sayısının, kontrasepsiyon ile ilgili bilgi alma durumunun ve ileriye yönelik gebelik düşüncesinin ilişkili olduğu belirlenmiştir. Sağlık profesyonelleri tarafindan üreme döneminde olan kadınlara hastalık bilgisi ve yönetimine yönelik yapılan danışmanlığa ek olarak; plansız ve riskli gebeliklerin önlenmesi, hedef glisemik değere sahip olunarak gebe kalınması amacıyla kontrasepsiyon kullanımı ile ilgili danışmanlığın yapılması, kontrasepsiyon kullanma davranışının her sağlık kontrolünde değerlendirilmesi önerilmektedir. Ayrıca, daha geniş örneklem grubuyla çalışmaların yapılması, kontrasepsiyon kullanımı ile ilgili ilişkili olan faktörlerin belirlenmesine katkı sağlayacaktır. 


\section{Yazarların Makaleye Katkı Beyanı}

Çalışma konusunun belirlenmesi, literatür taraması, çalışmanın düzenlenmesi (\%30): Selda Çelik, Feride Taşkın Yılmaz, Anketlerin düzenlenmesi ve istatistik çalışmaların yapılması (\%20): Feride Taşkın Yılmaz, Gülden Anataca, Elif Bülbül, Çalışmanın yazım aşamasında literatür araştırması ve çalışmanın tartışma kısmının yazımı (\%20): Selda Çelik, Feride Taşkın Yılmaz, Katılımcılarla görüşülmesi ve genel bilgilerin alınması, anketlerin yapılması (\%20); Gülden Anataca, Elif Bülbüll, Çalışma istatistiğinin değerlendirilmesi ve düzenlenmesi (\%5): Feride Taşkın Yılmaz, Çalışmanın son gözden geçirilmesi süreci (\%5): Selda Çelik.

\section{Çıkar Çatışması}

Yazarların beyan edecek herhangi bir çıkar çatışmaları yoktur.

\section{Finansal Destek}

Bu çalışmanın yapılabilmesi için herhangi bir finansal destek alınmamıştır.

\section{Etik Kurul Onayı}

Sağlık Bilimleri Üniversitesi Kanuni Sultan Süleyman Eğitim ve Araştırma Hastanesi Klinik Araştırmalar Etik Kurulundan (Karar No: KAEK/2020.12.223) gerekli etik kurul onayı alınmıştır.

\section{Hakem Değerlendirmesi}

Hakemlerin değerlendirmeleri sonrası yayınlanmaya uygun bulunmuştur.

\section{KAYNAKLAR}

1. Saeedi P, Petersohn I, Salpea P, Malanda B, Karuranga S, Unwin N, Colagiuri S, Guariguata L, Motala AA, Ogurtsova K, Shaw JE, Bright D, Williams R; IDF Diabetes Atlas Committee. Global and regional diabetes prevalence estimates for 2019 and projections for 2030 and 2045: Results from the International Diabetes Federation Diabetes Atlas, 9th edition. Diabetes Research and Clinical Practice. 2019;157:107843.

2. Leow SN, Tang WS, Pararajasingam RP, Ee WS. Patient perception of pre-pregnancy care and family planning among reproductive-age female diabetes mellitus patients in a primary care clinic in Penang, Malaysia. Malays Fam Physician. 2020;15(3);35-42.

3. Robinson A, Nwolise C, Shawe J. Contraception for women with diabetes: Challenges and solutions. Open Access Journal of Contraception. 2016;7:11-18.

4. Pallardo LF, Cano A, Cristobal I, Blanco MA, Lozano M, Lete I. Hormonal contraception and diabetes. Clinical Medicine Insights: Women's Health. 2012;5:53-63.

5. Aksu H, Gökdemirel SÖ. Diyabetli kadınlarda kontrasepsiyon seçimi. STED. 2012;21(2):70-73.

6. Yıldırım Şimşir I, Özkan Derviş V, Çetinkalp Ş. Diyabetli gebelerde sürekli subkutan insülin infüzyon tedavisi. Türk Diyab Obez 2017;1(2):73-76.

7. Shawe J, Smith P, Stephenson J. Use of contraception by women with type 1 or type 2 diabetes mellitus: 'It's funny that nobody really spoke to me about it'. Eur J Contracept Reprod Health Care. 2011;16(5):350-358.
8. Shawe J, Lawrenson R. Hormonal contraception in women with diabetes mellitus: Special considerations. Treat Endocrinol. 2003;2(5):321-230.

9. Watts S. Contraception advice for young people with diabetes. Buckinghamshire Healthcare. 2020.

10. Britton LE, Hussey JM, Berry DC, Crandell JL, Brooks JL, Bryant AG. Contraceptive use among women with prediabetes and diabetes in a us national sample. J Midwifery Womens Health. 2019;64(1):36-45

11. Damm P, Mathiesen E, Clausen TD, Petersen KR. Contraception for women with diabetes mellitus. Metab Syndr Relat Disord. 2005;3(3):244-249.

12. Walker SL, Anguzu R, Egede LE, Palatnik A. Contraception preferences in women with diabetes. Diabetes. 2020;69(Supp1).

13. MacKay L, Glasier A, McKnight JA. Contraception for women with diabetes mellitus. Pract Diab Int. 2005;22(2):49-52.

14. Law DS, Tan CE, Tong SF. Influences on the decision to use contraception among Sarawakian women with diabetes: A qualitative exploration. Sex Reprod Health Matters. 2019;27(1):1571316.

15. Schwarz EB, Maselli J, Gonzales R. Contaceptive counseling of diabetic women of reoroductive age. Obstet Gynecol. 2006;107(5):1070-1074.

16. Shave J, Mulnier H, Nicholfs R, Lawrenson R. Use of hormonal contraceptive methods by women with diabetes. Prim Care Diabetes. 2008;2(4):195-199.

17. Nikolov A, Dimitrov A, Kolarov G, Todarova K, Mekhandzhiev TS. Contraception in women with diabetes mellitus. Akush Ginckol. 2005;44(5):47-52.

18. Visser J, Snel M, Van Vliet HA. Hormonal versus nonhormonal contraceptives in women with diabetes mellitus type 1 and 2. Cochrane Database Syst Rev. 2013;3:CD003990.

19. World Health Organization (WHO). Medical eligibility criteria for contraceptive use, Fifth edition, 2015. Geneva: WHO 2009. Accessed 20 February 2021 from: https://www. who.int/publications/i/item/9789241549158

20. Durand M, Armenta A. Contraception and Hormonal Therapy in Women with Diabetes Mellitus. J Diabetes Metab. 2015;6:554.

21. Johnson EH, Wu J. Contraceptive decision making among women with diabetes mellitus: A mixed methods study. Journal of Clinical and Translational Science. 2020;4(1):127.

22. Aksu H, Yurtsev E. Gebelik, diyabet ve hemşirelik bakımı. Hacettepe Üniversitesi Hemşirelik Fakültesi Dergisi. 2009; 16(3): 50-58.

23. Vahratian A, Barber JS, Lawrence JM, Kim C. Family-planning practices among women with diabetes and overweight and obese women in the 2002 national survey for family growth. Diabetes Care. 2009;32:1026-1031.

24. Evangelista DR, Moura ERF, Costa CBJS, Bezerra CG, Valente MMQP, de Sousa CSP. Contraception: Knowledge and practice among women with Diabetes Mellitus. Esc Anna Nery. 2014;18(3):441-447. 